\title{
EVALUATION AVAILABILITY OF NARCOTICS AND PSYCHOTROPICS IN PHARMACY IN MEDAN CITY REGION
}

\section{JULIA SUSANTI, JULIA REVENY*, WIRYANTO}

Department of Faculty of Pharmacy, Universitas Sumatera Utara, Medan, Indonesia. Email: wiryanto_2510@yahoo.com

Received: 21 November 2017, Revised and Accepted: 13 April 2018

\begin{abstract}
Objective: The purpose of this study is to find out what percentage of pharmacies that provide and report drug classes and narcotics with psychotropic SIPNAP and find out why.

Materials and Methods: This research use descriptive method using questionnaire instrument to 85 pharmacists in charge of pharmacy (APA) and 85 owners of pharmacy capital (PMA), then data are processed using SPPS windows.

Results: The results of the questionnaire on the answers of respondents APA and PMA showed pharmacies that provide drugs class of narcotics and psychotropic in Medan 67 (43.51\%), which provides narcotics only 2 (1.30\%), which provides psychotropic drugs only 21 (13.64\%) and pharmacies that do not provide drugs class of narcotics and psychotropic 64 (41.56\%). The most common reason for narcotics and psychotropic drugs is the demand for prescription drugs at pharmacies 38 (86.36\%), whereas the most reason for not providing narcotics and psychotropic drugs is that there are no or very few prescriptions of narcotics and psychopathic drugs that go into pharmacies 31 (75.61\%).
\end{abstract}

Conclusion: While reporting the result that reported drug with narcotic program online (SIPNAP) 46 (29.87\%) with the reason most because not understand how to make and send report SIPNAP $41(85.42 \%)$.

Keywords: Availability, Reporting, Narcotics, Psychotropic, Reason.

(C) 2018 The Authors. Published by Innovare Academic Sciences Pvt Ltd. This is an open access article under the CC BY license (http://creativecommons. org/licenses/by/4. 0/) DOI: http://dx.doi.org/10.22159/ajpcr.2018.v11i7.23787

\section{INTRODUCTION}

Indonesian society is prosperous, fair, and prosperous that is evenly materially and spiritually, then to realize it needs to improve the quality of human resources as one of the national developments capital must be maintained and improved continuously, including the degree of health. Increasing the public health degree by making efforts in improving the field of medicine and health services, among others, by seeking the availability of certain types of narcotics are needed as a medicine [1].

Annual drug requirements plan of narcotic drugs needs to be prepared to ensure the availability of narcotics drugs. The annual requirements plan of narcotics is prepared based on data on recording and reporting of annual plans and realized annual production that are audited comprehensively and guides the procurement, control, and supervision of narcotics drugs nationally, the meaning of article 9 paragraph 2 and 3 of Act No. 35 of 2009 on narcotics [2].

Permenkes RI number 26 of 2014 on article 2, paragraph 1 and 2 of the annual requirement plan of narcotics, psychotropic, and precursors stated that "in order to guarantee the availability of narcotics and psychotropic for the benefit of health services and/or for the development of science and technology, the Minister prepares the need plan annual narcotics and annual psychotropic need plan" [3].

Furthermore, in article 2, paragraph 4 and 5 Permenkes RI number 26 year 2014 said "the annual requirement plan of narcotics, psychotropic, and precursor is used as a basis to determine the needs of 1 year of narcotics, psychotropic, and precursors. The annual demand plan for narcotics, psychotropics, and precursors is prepared for 1 year from January 1 to December 31" [3].

Pharmaceutical plan and pharmacy strategy plan one of them is by increasing availability, distribution, and affordability of medicines and medical devices as well as to guarantee the security/efficacy, benefit and quality of pharmaceutical, medical devices, and food preparation [4]

Psychotropic drugs are important for medication. Depression and morbid anxiety are the most common type of neurotic disorders which have affected the productivity of nations worldwide in terms of economic and workforce loss. Depression is characterized by severe negative and nihilistic thoughts (life is not worth living), the intense sadness of mood, loss of interest in routine work, low or high appetite, insomnia, and severe suicidal tendency. Similarly, anxiety neurosis is accompanied by autonomic overactivity leading to tachycardia, tremors, sweating, loss of confidence, etc., for work [5]. Psychotropics such as alprazolam are a synthetic, short-acting anxiolytic of the benzodiazepine class and used to treat anxiety disorders, panic attacks, and anxiety caused by depression [6]

The level of drug availability is the ability of pharmaceutical facilities to provide medication according to the prescription or the patient's request for prescription service. The drug void is strongly associated with procurement management and drug control and to improve the availability of medication requires careful planning of drug requirements [7].

\section{MATERIALS AND METHODS}

\section{Materials}

The sample in this study was from a population that met the inclusion criteria. The sample size is determined by Slovin formula where this formula is used when the number of population $(\mathrm{N})$ is known as 583 pharmacies. The number of pharmacies that will be included as samples is 85 pharmacists and 85 pharmaceutical capital owners, respectively.

\section{Methods}

This research is conducted with the following steps:

- Requesting the recommendation of the Dean of the Faculty of 
Pharmacy USU and Head of Health Office of Medan City to be able to conduct research in pharmacies of the city of Medan.

- Providing information on opening and questioning techniques to respondents.

- The questionnaire instrument is handed out in manual form and/ or Google drive through WhatsApp, Email, and manual. And give the questionnaire directly to Medan city pharmacies based on $\%$ of urban districts in Medan to \pm 200 respondents with a recommendation letter from the Faculty of Pharmacy Universitas Sumatera Utara and Medan City Health Office.

- Any answers filled through WhatsApp or Email, then the answer will automatically be answered all. However, answer manually, then the authors will recheck the questionnaire whether it has filled all. If there is not yet filled, then the authors will ask the answer questionnaire that is not filled so that all the questionnaires received are a questionnaire that has filled all. If the answer is complete, then the questionnaire will be moved WhatsApp premises Google drive program.

- Collecting questionnaires data from APA and PMA. The data can be processed with SPSS program.

- The results obtained data and information obtained will be analyzed and evaluated so that the conclusion obtained research.

\section{RESULTS AND DISCUSSION}

Total of 170 APA and PMA correspondents, there are 16 pharmacies with APA and PMA of the same name and address of the pharmacy, to obtain total correspondence with different pharmacies names of 154 pharmacies.

Referring to Table 1 it can be seen that from 154 pharmacies, $64(41.56 \%)$ of pharmacies do not provide drugs class of narcotics or psychotropic, $2(1.30 \%)$ pharmacies provide drug only drug group, $21(13.64 \%)$ pharmacies provide only psychotropic drugs, and $67(43.51 \%)$ of pharmacies provide drugs class of narcotics and psychotropic

Table 1: Description of the availability of narcotics and psychotropic drugs total availability of narcotics and psychotropic drugs

\begin{tabular}{ll}
\hline Drug availability & Amount (\%) \\
\hline $\begin{array}{l}\text { Not providing drugs class of narcotics } \\
\text { and psychotropic }\end{array}$ & $64(41.56)$ \\
Providing narcotic drugs only & $2(1.30)$ \\
Providing psychotropic drugs only & $21(13.64)$ \\
Providing drugs class of narcotics and & $67(43.51)$ \\
psychotropic & \\
Total & $154(100)$ \\
\hline
\end{tabular}

The above data can be seen that pharmacies that do not provide at all drugs drug category of $64(41.56 \%)$ pharmacies, this condition shows the professional function of pharmacies as providers and service providers less good or not optimal and can make it difficult for patients in search such drugs.

\section{CONCLUSION}

The pharmacies that provide narcotics and psychotropic drugs in Medan city area $(43.51 \%)$, which provide narcotics alone $(1.30 \%)$, which provide only psychotropic drugs $21(13.64 \%)$ and pharmacies that do not provide drugs class of narcotics and psychotropic 64 (41.56\%).

\section{ACKNOWLEDGMENTS}

The authors gratefully acknowledge to all the parties involved in this research, especially to all staffs of the pharmacy faculty of Universitas Sumatera Utara.

\section{AUTHOR'S CONTRIBUTION}

The first author has carried out the research. Second and third authors have provided study conception, the design of work, drafting of the manuscript, and critical revision.

\section{CONFLICTS OF INTEREST}

The authors declared that they have no conflicts of interest.

\section{REFERENCES}

1. President of Indonesia. Laws of Indonesian Republic Number 51 Years 2009 About Pharmaceutical Jobs. Jakarta: Lembaran Negara Republik Indonesia; 2009.

2. President of Indonesia. Laws of Indonesian Republic Number 35 Years 2009 About Narcotic. Jakarta: Lembaran Negara Republik Indonesia; 2009.

3. Ministry of Health of Republic of Indonesia. Decree of the Ministerof Health of the Republic of Indonesia Number 35 Years 2014 About Standard Service of Pharmaceutical Care in Pharmacys. Jakarta: Kemenkes; 2014.

4. Director General of Pharmaceutical and Medical Devices. Narcotics and Psychotropic Reporting System. Bandung: Ministry of Health; 2011.

5. Hemant T, Prem N, Shubham A, Ritesh C. Evaluation of antianxiety, antidepressant and sedative effects of nimodipine in swiss albino mice. Int J Pharm Pharm Sci 2016;8:260-3.

6. Asha BT, Ashish N, Snehal SK. Determination of alprazolam and fluoxetine $\mathrm{HCl}$ from spiked rat plasma using Hptlc with uv detection. Int J Pharm Pharm Sci 2016;8:147-51.

7. Hadi IS, Satibi, danMurti T.A. Analysis of Pharmaceutical Installation Performance of X Regional Hospital With Balanced Scorecard Approach To Perspective Internal Business Process. Proding Seminar Nasional; 2015. 